\title{
EXPENDITURE PATTERN IN NIGERIAN UNIVERSITIES: MOVING RESOURCES FROM ADMINISTRATION TO RESEARCH AND PUBLIC SERVICE
}

\author{
Joel B. Babalola \\ Department of Education Management, University of lbadan, Nigeria
}

The expenditure pattern in Nigerian universities is expected to be influenced by the National Universities Commission (N.U.C.) through its costing and staffing parameters. In 1977, the NUC developed a series of such parameters to be used in the annual process of budget allocation to particular universities. These parameters, which are constantly reviewed, included the proportions of total recurrent budget for direct teaching, teaching supports, research, public service, library, staff development and general academic which are generally referred to as academic function. Moreover, the parameters included the percentage of budget of student services, general administration, retirement benefits and other non-academic expenditures.

Nevertheless, as rightly observed by the World Bank (1988:6): Although allocations are made to (Nigerian) universities on the basis of... norms, the funds are provided as block grant, with virtually no control over how they are used.

Consequently:

Only 34\% of expenditure go to direct teaching while total academic costs, including libraries and research units, claim only 49\%. Over half of total expenditures

are devoted to administrative support in various forums. The comparable figure for British universities is under 39\%... IDA (1990:6)

The consequential effects of the inefficient university funds allocation have become a source of concern to researchers in higher education. The IDA (1990) for instance, said that the structure of unit costs in Nigerian universities demonstrates why "there is widespread evidence of under-funding of many academic activities and inputs". According to the World Bank (1988), only the NUC parameter universally exceeded by Nigerian universities is that for senior administrative staff.

Recent findings (Babalola et. al., 1996) have also confirmed a significant overspending on general administration at the expense of research and public service in Nigerian universities. On the average, general administrative expenditure which ought to be $5.6 \%$ of the total money, attracted as high as $15.04 \%$ and $10.66 \%$ in $1991 / 92$ and $1992 / 93$ respectively. Whereas, $2.56 \%$ and $2.15 \%$ of the recurrent expenditures were spent on research in 1991/92 and 1992/93 against the recommended 8\%. Similarly, public service shared $2.01 \%$ in $1991 / 92$ and $1.78 \%$ in $1992 / 93$ against the recommended $3 \%$. 


\section{Annals of the Social Science Council of Nigeria, No. 8, January-December, 1996}

Based on the above background, this paper discussed some measures considered useful for moving resources from the over-emphasized items of expenditure to research and public services, which are two main functions of a university.

\section{Methodology}

Nigerian government seems to have reached her fiscal ceilings in respect of sustained support for university education. It becomes necessary therefore, to make more efficient use of the available resources to revitalize the pedagogical situations. It is against this background that this paper attempts to provide proposals for Nigerian universities to restructure their spending pattern. To this end, this study focuses ort historical analysis of university costs.

Nigeria has both state and federal universities. This study is limited to 10 out of the 21 federally funded universities as at 1993. The study adopts a cross-university design to collect 1991 /91 actual data on recurrent expenditures and other available information from files and documents of the sampled universities stratified according to age and geographical location.

Eight variables have been identified as contributing to the variation in the spending behaviour of Nigerian universities, namely; enrolment size (ES), student' teacher ration (STR), junior/senior staff ratio (JSSR), non-academic/academic staff ratio (NAASR), goods cost per student (GCPS), spending deviation (SD), grant-effectiveness ratio (GER) and weighted curriculum type (CTW),

The ordinary least squares (OLS) in the contest of multiple regression have been adopted as the estimation procedure. The resulting the null hypothesis that each partial regression parameter is zero at $10 \%, 5 \%$ and $1 \%$ levels of statistical significance when $\mathrm{N}$ $=10$. The adjusted coefficients of determination show that each of the ARSHC, APSC and AASC equations is quite a good fit. Moreover, most of the partial parameters have small values of standard errors.

\section{Results and Discussions}

The results are presented under the following sub-titles to reflect the specific research questions.

\section{Unit cost analysis}

Nigeria spent N5903.50 or US\$671.62 on each university student in 1991792 when the exchange rate was US\$1 toN8.79. Contrary to expectation, the recurrent expenditure on a university student in Nigeria which has been judged to be "very low compared to those of universities in developed countries" (IDA 1990), has remained almost the same between 1985 (US\$600) and 1991 (US\$672), in spite of the high inflation rates within this period. 
Table 1 is on the recurrent expenditure per student by discipline and university in Nigeria. Unit cost varied by university with N3332 or US\$379 per student in Jos while Akure was the most costly university with N8351 or US\$950 per student.

As far as relative expensiveness of university disciplines is concerned, four main groups of disciplines can be identified (Table 1). Those with low recurrent cost per student included courses in Administration, Arts, Education, Law, Pharmacy, Sciences and Social Science. For these disciplines, the unit cost ranged from N1230 or US\$140 to N3180 or US\$362.

Agriculture and Environmental Science were average-cost disciplines with unit cost ranging between N3181 or US\$362 and N3934 or US\$448. Medicine with unit cost ranging from N3935 or US $\$ 448$ to $\mathrm{N} 11468$ or US $\$ 1305$ can be considered as a moderately high-cost discipline. Of course, the most expensive discipline was Veterinary Medicine with cost ranging from N12033 to US\$3369 to N14984orUS\$1705.

From the above discussion, it may not be desirable to reduce the expenditure per student in Nigeria universities. However, there is need to carry out some structural adjustments in the spending pattern of Nigerian universities. This is to correct the seemingly long-established tilt towards administration at the expense of teaching, research and public service which are paradoxically the main purposes of a university. To this end, the following regression results can be considered as funds reallocation measures (Table 2).

\section{Increasing the enrolment in some courses}

Table 2 reveals that the higher the enrolment in Nigerian universities, the lower the administrative cost per student but the higher the amounts per student that will be available for research and public service.

Table 3 shows that universities in Nigeria operate below the optimum sizes in most disciplines (optimum sizes have been estimated graphically by plotting both the Marginal Costs (MC) and the Average Total Costs (ATS) by university. The intersections of the two curves indicate the minimum points of the ATC and hence, the option sizes).

The finding supports the earlier ones by the World Bank (1988). However, there is need for caution, since the optimum sixes, as calculated either by the World Bank (3988) or in this study, ignore the nationally recommended student/teacher ratios for various disciplines. The issue of expanding enrolment at the face of the overcrowding of student hostel facilities, science laboratories, engineering workshops, and libraries that many campuses have to cope with apart from shortage of academic staff in science disciplines must first be tackled. 
As a solution, the World Bank (1988; suggested that a three-semester system could be introduced, with each student attending only two semesters. According to them, teachers accruing more than an agreed number of student contact hours per year may have to be paid some overtime to teach the third semester. According to the World Bank (1988), this spreading out of student enrolments throughout the year would enable "savings in non-teaching staff'. The savings can then be ploughed into research and public service.

\section{Reducing the number of senior staff where there is excess}

Table 2 reveals that the more the junior/senior staff ration, the less the administrative expenditure per student but the higher the research and public service expenditures per student. To achieve this, two main methods can be used. First, more junior staff can be employed. Two, the number of senior staff can be reduced. The second option seems to be attractive to the World Bank. It should however, be noted that junior and senior staff is not substitutable. Both are needed but in the right ratio.

According to the World Bank (1988), the only NUC parameter universally exceeded by Nigerian universities is that for senior administrative staff. Moreover, priority often seems to be given to the rehabilitation or construction of administrative buildings and when budgets are cut the share of administrative expenditures tends to rise. Based on these, the Bank suggested a complete freeze on the recruitment of both senior and junior administrative staff.

Furthermore, a planned phase of senior staff in Nigeria is one of the conditions for receiving the international Development Association (IDA) loan. According to the IDA (1990), to meet the first tranche criteria, a university in Nigeria will have selected and named half of the excess non-academic staff to be removed, for the second tranche, dismissed all excess non-academic staff, and for the third tranche removed from the payroll, half excess academic staff. Savings from this retrenchment and freeze has been calculated by the World Bank to be N26 million per annum. This saving can be used to finance research and public service.

Nevertheless, experience shows that the senior administrative staff is composed of various types of workers including typists and drivers. There is need to attempt a reclassification of this category of staff before any reasonable retrenchment can be embarked upon. The criterion for classifying a staff as senior, should be revisited and probably be reviewed.

\section{Increasing the number of academic staff where necessary}

Table 2 predicts that a reduction in non-academic staff ratio will lead to increases in research and public service costs per student, but to a corresponding 
reduction in the unit administrative cast. This can be achieved by either retrenching nonacademic staff (junior and senior) or increasing the number of academic staff.

There is no doubt that university teachers in Nigeria are currently over utilised following tie exodus, outside the country, of many academic staff in search of greener pasture. If the number of students to be taught by a teacher is decreased, as suggested in this paper, then there will be more time for research and public service. Moreover, the NUC appropriations on research and public service will increase relative to the size of academic staff.

\section{Changing economic rates of utilities like electricity}

Table 2 reveals that the less the recurrent expenditure per student devoted to goods and services, the more the average research and public service costs but the less the administrative cost per student. Since administrative expenditure is made up of goods and services, plant and ground, student services and general administrative expenditure, any attempt to reduce the amount expended on goods and services will go a long way to reduce administrative cost.

There is need to look very closely at ways by which universities can reduce expenses on the so-called free services on campuses. These expenses are assocjk ated with electricity, water, telephone, and waste disposals. The situation where a; university spends about 25 percent of its quarterly subvention on paying electricity bill is questionable. This 25 percent does not include the cost of electricity generated locally through generating plants where there is power failure. It is doubtful if residents on campuses are charged the economic rates of utilities supplied to them. In fact, tenants (including those in rented shops are not likely to be paying the commensurate rates of the utilities used. Students, staff and other tenants on campuses are therefore, heavily subsidized.

Universities should therefore, recover some costs from tenants and residents by charging them for utilities (water, electricity, telephone) as well as refuse disposals. The recovered costs should be used to supplement expenditures on research and public service. Nevertheless, the low wage level of university teachers may create an initial bottleneck.

\section{Reducing the number of universities offering human and veterinary medicine}

Table 2 shows that the lower the weighted cost of the curriculum operated in a university, the less the average administrative support cost but the higher the average costs of research and public service. This finding supports earlier ones that it is cheaper to run classroom-based than laboratory-based courses (Kumar 1981 and Akangbou 1986). 
While this paper does not recommend mat universities should de-emphasis heavycost courses (Medical Science and Veterinary Medicine), it may be necessary to operate these heavy-cost courses inlfewer universities than hitherto. In fact, the World Bank (1988) reveals that almost all Nigerian universities offer courses in medicine... and enrolments... at the newer universities are well below an economically effective level. Table 3 further reinforces this by revealing that, apart from Calabar and Ibadan, Medical Science was sub-optimally operated in all sampled universities in 19991/91. In fact, none of the universities in sample operated Veterinary Medicine at optimal level. The total veterinary medicine enrolment ranged from 145 in Maiduguri through 449 in Ibadan to 454 in Zaria in 1991/92 session.

Thus, to reduce the administrative cost of these heavy-cost courses and therefore, enjoy the advantages of economies of scale, Nigeria should, without sentiment, reduce the number of universities operating these two disciplines to about four - two in the North and two in the* South. However, efforts must be made to avoid diseconomies of scale as enrolments beyond the optimum sizes by disciplines might shoot up the cost per student or lead to a poorer quality of university education.

\section{Reducing the spending deviation from ceilings}

Table 2, lastly, .shows that by reducing the spending deviation, the unit administrative cost will be reduced and those of research and public service will be increased. As rightly suggested by the World Bank (1988) as well as the IDS (1990), the NUC should enforce its costing parameters to the detail to ensure compliance and hence reduce adverse deviation in spending to the Bearable minimum. By so doing, money will be moved from administrative supports to research and public service hitherto neglected. The next section deals with the relevance and limitation of this paper.

\section{Relevance and Limitations}

Practitioners within Nigerian universities and the NUC will find this paper useful as a guide during the preparation of recurrent estimates, and if need be, as an information document in the process of making decisions on expenditure control and cost reduction, recovery and reallocation. This paper will particularly be found useful while proposing a reduction in the administrative costs of a Nigerian University in particular, and as lessons for all African universities in general.

Nevertheless, practitioners should carefully study each of the suggested measures to ensure that it applies to the situation at hand before any attempt to implement it. This is because the measures, as suggested, were drawn mainly from the 1991/1992 expenditure data often sampled universities in Nigeria. To come 


\section{Expenditure Pattern in Nigerian Universities: Moving Resources from Administration 55}

Table 1: Recurrent expenditure by discipline and university in Nigeria 1991-92

\begin{tabular}{|c|c|c|c|c|c|c|c|c|c|c|c|c|c|c|c|c|c|c|c|}
\hline & $\begin{array}{l}\mathrm{AD} \\
\mathrm{M}\end{array}$ & $\begin{array}{l}\text { AGRI } \\
\text { C }\end{array}$ & $\begin{array}{l}\text { ART } \\
\text { S }\end{array}$ & $\begin{array}{l}\text { EDU } \\
\text { C }\end{array}$ & $\begin{array}{l}\text { ENG } \\
\mathrm{N}\end{array}$ & $\begin{array}{l}\text { ENV } \\
\text { I }\end{array}$ & $\begin{array}{l}\text { LA } \\
\text { W }\end{array}$ & $\begin{array}{l}\mathrm{ME} \\
\mathrm{D}\end{array}$ & $\begin{array}{l}\text { PHA } \\
\mathrm{R}\end{array}$ & $\mathrm{SCI}$ & $\begin{array}{l}\text { SOCS } \\
\text { CI }\end{array}$ & VET & $\begin{array}{l}\mathrm{AL} \\
\mathrm{L} \\
\mathrm{DIS} \\
\mathrm{C}\end{array}$ & TS & $\begin{array}{l}\text { RS } \\
\mathrm{H}\end{array}$ & PS & $\mathrm{OA}$ & AS & $\begin{array}{l}\text { OD } \\
T\end{array}$ \\
\hline AKURE & - & $\begin{array}{l}2609 \\
8778\end{array}$ & - & - & $\begin{array}{l}1479 \\
7649\end{array}$ & $\begin{array}{l}5085 \\
1125 \\
5\end{array}$ & - & & - & $\begin{array}{l}211 \\
0 \\
827 \\
9 \\
\end{array}$ & - & - & $\begin{array}{l}218 \\
1 \\
835 \\
1 \\
\end{array}$ & $\begin{array}{l}26 \\
3\end{array}$ & 51 & 54 & 795 & $\begin{array}{l}500 \\
4\end{array}$ & 2 \\
\hline BENIN & - & $\begin{array}{l}1605 \\
5207\end{array}$ & $\begin{array}{l}1850 \\
5452\end{array}$ & $\begin{array}{l}670 \\
4272\end{array}$ & $\begin{array}{l}2087 \\
5689\end{array}$ & - & $\begin{array}{l}112 \\
3 \\
472 \\
5 \\
\end{array}$ & $\begin{array}{l}2193 \\
5795\end{array}$ & $\begin{array}{l}2588 \\
6190\end{array}$ & $\begin{array}{l}142 \\
2 \\
502 \\
4 \\
\end{array}$ & $\begin{array}{l}938 \\
4540\end{array}$ & - & $\begin{array}{l}140 \\
7 \\
500 \\
9 \\
\end{array}$ & 42 & 25 & 36 & 867 & $\begin{array}{l}263 \\
2\end{array}$ & 0 \\
\hline CALABAR & - & $\begin{array}{l}1394 \\
4711\end{array}$ & $\begin{array}{l}2325 \\
6313\end{array}$ & $\begin{array}{l}785 \\
4773\end{array}$ & - & - & $\begin{array}{l}805 \\
479 \\
5\end{array}$ & $\begin{array}{l}3536 \\
7524\end{array}$ & - & $\begin{array}{l}173 \\
3 \\
572 \\
1 \\
\end{array}$ & $\begin{array}{l}1889 \\
5877\end{array}$ & - & $\begin{array}{l}185 \\
2 \\
584 \\
1 \\
\end{array}$ & - & 403 & $\begin{array}{l}37 \\
3\end{array}$ & 509 & $\begin{array}{l}267 \\
8\end{array}$ & 46 \\
\hline IBADAN & - & - & $\begin{array}{l}2301 \\
3643\end{array}$ & $\begin{array}{l}1461 \\
2803\end{array}$ & $\begin{array}{l}3016 \\
4358\end{array}$ & & $\begin{array}{l}198 \\
1 \\
332 \\
3 \\
\end{array}$ & $\begin{array}{l}5731 \\
7073\end{array}$ & - & $\begin{array}{l}243 \\
2 \\
377 \\
4 \\
\end{array}$ & $\begin{array}{l}1615 \\
2957\end{array}$ & $\begin{array}{l}7497 \\
8839\end{array}$ & $\begin{array}{l}297 \\
5 \\
641 \\
1 \\
\end{array}$ & $\begin{array}{l}10 \\
7\end{array}$ & 286 & $\begin{array}{l}14 \\
8\end{array}$ & 224 & $\begin{array}{l}262 \\
5\end{array}$ & 46 \\
\hline JOS & - & - & $\begin{array}{l}1012 \\
3261\end{array}$ & $\begin{array}{l}634 \\
2879\end{array}$ & - & $\begin{array}{l}1295 \\
5909\end{array}$ & $\begin{array}{l}671 \\
292 \\
0\end{array}$ & $\begin{array}{l}4262 \\
6511\end{array}$ & $\begin{array}{l}2859 \\
5108\end{array}$ & $\begin{array}{l}221 \\
4 \\
446 \\
3 \\
\end{array}$ & $\begin{array}{l}411 \\
2660\end{array}$ & - & \begin{tabular}{|l|l}
108 \\
3 \\
333 \\
2 \\
\end{tabular} & 41 & 28 & -- & 237 & $\begin{array}{l}194 \\
3\end{array}$ & \\
\hline LAGOS & $\begin{array}{l}139 \\
2 \\
600 \\
6 \\
\end{array}$ & - & $\begin{array}{l}3803 \\
8417\end{array}$ & $\begin{array}{l}1743 \\
6357\end{array}$ & $\begin{array}{l}3367 \\
7981\end{array}$ & $\begin{array}{l}2845 \\
7459\end{array}$ & $\begin{array}{l}261 \\
5 \\
722 \\
9 \\
\end{array}$ & $\begin{array}{l}8360 \\
1297 \\
4\end{array}$ & - & $\begin{array}{l}278 \\
4 \\
739 \\
8 \\
\end{array}$ & $\begin{array}{l}1729 \\
6343\end{array}$ & - & $\begin{array}{l}289 \\
5 \\
751 \\
0 \\
\end{array}$ & 75 & 219 & $\begin{array}{l}14 \\
6\end{array}$ & 589 & $\begin{array}{l}346 \\
2\end{array}$ & 123 \\
\hline $\begin{array}{l}\text { MAIDUGU } \\
\text { RI }\end{array}$ & - & $\begin{array}{l}5167 \\
9163\end{array}$ & $\begin{array}{l}2776 \\
6772\end{array}$ & $\begin{array}{l}1442 \\
5438\end{array}$ & $\begin{array}{l}7894 \\
1189 \\
0\end{array}$ & - & $\begin{array}{l}311 \\
0 \\
710 \\
6 \\
\end{array}$ & $\begin{array}{l}2176 \\
7 \\
2576 \\
3 \\
\end{array}$ & - & $\begin{array}{l}327 \\
0 \\
726 \\
6 \\
\end{array}$ & $\begin{array}{l}1206 \\
5202\end{array}$ & $\begin{array}{l}2777 \\
2 \\
3176 \\
8 \\
\end{array}$ & \begin{tabular}{|l|l}
349 \\
0 \\
748 \\
6 \\
\end{tabular} & $\begin{array}{l}19 \\
3\end{array}$ & 299 & $\begin{array}{l}18 \\
6\end{array}$ & $\begin{array}{l}136 \\
3\end{array}$ & $\begin{array}{l}191 \\
7\end{array}$ & 38 \\
\hline $\begin{array}{l}\text { PHARCOU } \\
\text { RT }\end{array}$ & $\begin{array}{l}569 \\
367 \\
6\end{array}$ & - & $\begin{array}{l}1310 \\
4117\end{array}$ & $\begin{array}{l}1868 \\
4975\end{array}$ & $\begin{array}{l}1592 \\
4699\end{array}$ & - & - & $\begin{array}{l}4747 \\
7854\end{array}$ & - & $\begin{array}{l}234 \\
4 \\
545 \\
1\end{array}$ & $\begin{array}{l}1227 \\
4334\end{array}$ & - & $\begin{array}{l}158 \\
0 \\
468 \\
7\end{array}$ & 59 & 123 & $\begin{array}{l}11 \\
8\end{array}$ & 533 & 228 & 46 \\
\hline UYO & $\begin{array}{l}131 \\
5 \\
502 \\
7 \\
\end{array}$ & $\begin{array}{l}6502 \\
10214\end{array}$ & $\begin{array}{l}3495 \\
7287\end{array}$ & $\begin{array}{l}1472 \\
5184\end{array}$ & - & - & $\begin{array}{l}257 \\
5 \\
628 \\
7 \\
\end{array}$ & - & - & $\begin{array}{l}169 \\
3 \\
532 \\
6\end{array}$ & $\begin{array}{l}2002 \\
5714\end{array}$ & - & $\begin{array}{l}192 \\
1 \\
563 \\
3 \\
\end{array}$ & $\begin{array}{l}43 \\
9\end{array}$ & 66 & 77 & 391 & $\begin{array}{l}262 \\
6\end{array}$ & 113 \\
\hline ZARIA & $\begin{array}{l}907 \\
509 \\
2\end{array}$ & $\begin{array}{l}3672 \\
7857\end{array}$ & $\begin{array}{l}2437 \\
6622\end{array}$ & $\begin{array}{l}906 \\
5091\end{array}$ & $\begin{array}{l}4147 \\
8332\end{array}$ & $\begin{array}{l}4385 \\
8570\end{array}$ & $\begin{array}{l}823 \\
501 \\
7\end{array}$ & $\begin{array}{l}4259 \\
8444\end{array}$ & $\begin{array}{l}2000 \\
6185\end{array}$ & $\begin{array}{l}517 \\
2 \\
935 \\
7\end{array}$ & - & $\begin{array}{l}9027 \\
1739 \\
7\end{array}$ & $\begin{array}{ll}109 \\
0 \\
527 \\
5 \\
\end{array}$ & $\begin{array}{l}10 \\
8\end{array}$ & 133 & 11 & 376 & $\begin{array}{l}336 \\
0\end{array}$ & 197 \\
\hline MEAN & $\begin{array}{l}104 \\
6 \\
\end{array}$ & 3474 & 2368 & 1220 & 3369 & 3403 & $\begin{array}{l}171 \\
4 \\
\end{array}$ & 6857 & 2482 & $\begin{array}{l}251 \\
7 \\
\end{array}$ & 1377 & $\begin{array}{l}1476 \\
5\end{array}$ & $\begin{array}{l}318 \\
1 \\
\end{array}$ & - & - & - & & 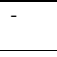 & - \\
\hline
\end{tabular}

NOTES (1) DT $=$ Direct Teaching ATC $=$ Average Total Cost, $\mathrm{TS}=$ Teaching Support, $\mathrm{RSH}=$ Research PS Public Services OA= Other Academic,

AS = Administrative Support plus retirement benefits

(2) Benin and Ibadan were operating Collegiate System Hence AVC includes College expenditure per student

(3) Standard Deviation of DT $=3934(6 n)$

SOURCE: (1) Expenditure figures from individual University Data Sheet and Estimates of Recurrent Operating Expenses 199495

(2) Enrolment Figures from National University Commission Statistical Digest on Nigerian Universities 19881992 pp 46-47 


\section{Annals of the Social Science Council of Nigeria, No. 8, January-December, 1996}

\section{Table 2 Explaining variation expenditure per student using regression coefficients $\mathrm{B}$ $\left(\mathrm{EX}^{4} \mathrm{XY}\right)$}

\begin{tabular}{|l|l|l|l|l|l|l|l|l|l|}
\hline Y8(AODT) & Y1(ATC) & Y2(ADTC) & Y3(ATSC) & Y4(ARSHC) & Y5(APSC) & Y6(AOAC) & Y7(AASC) & Y8(AODT & X5(ASS) \\
\hline CONSTANT & -1898.317 & 2951.513 & -1343.883 & $4044.6^{* * *}$ & $4471.6^{* * *}$ & 2563.487 & $-14450.7^{* * *}$ & -198.922 & 532959.348 \\
\hline (ES)X1 & -0.282 & -0.145 & -0.082 & $0.157^{* * *}$ & $0.179^{* * *}$ & 0.156 & $-0.569^{* *}$ & 0.022 & 23.709 \\
\hline (JSSR)X2 & -3034.169 & -818.811 & -349.979 & $436.7^{* * *}$ & $615.65^{* * *}$ & $1553.1^{* *}$ & $-1345.9^{* * *}$ & -135.675 & 210343.3 \\
\hline (NAASR)X3 & 2082.542 & 311.300 & 166.779 & $-263.3^{* * *}$ & $-366.2^{* * *}$ & -653.278 & $2735.59 * * *$ & 164.313 & -166464.4 \\
\hline (STR)X4 & 114.450 & 6.055 & 61.098 & $-122.3 * * *$ & $-136.7 * * *$ & -137.541 & $447.791^{* * *}$ & -3138 & -17685.446 \\
\hline (GCPS)X6 & 0.967 & -0.364 & 0.086 & $-0.29 * * *$ & $-0.282^{* * *}$ & 0.134 & $1.703 * * *$ & -0.013 & 18.426 \\
\hline (CTW)X7 & 260.197 & 174.899 & 60.860 & $-104.2^{* * *}$ & $-126.7 * * *$ & -24.681 & $299.956^{*}$ & -19.846 & -5254.500 \\
\hline (GER)X8 & -703.764 & -584.220 & -34.303 & $-671.8^{* * *}$ & $-668.8^{* * *}$ & -178.776 & $1605.181 * *$ & -174.212 & 23470.597 \\
\hline (SD)X9 & 125.975 & -61.799 & 70.115 & $-144.3^{* * *}$ & $-167.2 * * *$ & $-273.98^{*}$ & $693.93 * * *$ & 11.277 & 33094.127 \\
\hline $\mathrm{R}$ & 0.911 & 0.847 & 0.913 & 0.997 & 0.995 & 0.987 & 0.997 & 0.967 & 0.976 \\
\hline $\mathrm{R}^{2}$ & 0.830 & 0.717 & 0.833 & 0.994 & 0.989 & 0.975 & 0.993 & 0.934 & 0.953 \\
\hline Adjusted R $^{2}$ & 0.000 & 0.000 & 0.000 & 0.946 & 0.905 & 0.772 & 0.938 & 0.409 & 0.576 \\
\hline
\end{tabular}

NOTES: Significant at $10 \%$ Significant at $5 \%$ Significant at $1 \%$

1. Dependent Variables are average total (ATC) average direct teaching cost (ADTC), Average teaching support cost (ATSC), average research cost (ARSHC), average public service cost (APSC) average other academic cost (AOAC) average administrative support (AASC) average other teaching cost (AODT) and average staff salary (AAS)

2. Independent Variables are enrolment size (ES), Junior senior staff ratio (JSSR), Non-academic academic staff ratio (NAASR), Student teacher ratio (STR), Good cost per student (ACPS), ost (CTW) Grant effectiveness ratio (GER) and spending deviation (SD) 
Expenditure Pattern in Nigerian Universities: Moving Resources from Administration 57

TABLE 3. TOTAL STUDENT ENROLMENT AND OPTIMUM SIZE BY UNIVERSITY AND DISCIPLINE NIGERIA 1991-92

I

\begin{tabular}{|l|l|l|l|l|l|l|l|l|l|l|}
\hline DISCIPLINE & AKURE & BENIN & CALAB.AR & IB.AD.AN & JOS & LAGOS & MAIDUGURJ & $\begin{array}{l}\text { P } \\
\text { HARCOURT }\end{array}$ & tYO & Z.AR1A \\
\hline ADMIN & - & & & & & 1830 & & 1479 & 1141 & 2947 \\
\hline AGRJC & 418 & 598 & 837 & 1744 & - & & 607 & & 360 & 864 \\
\hline ARTS & & 1333 & 1094 & 1714 & 2104 & 1081 & 1358 & 1907 & 1047 & 2101 \\
\hline EtX'C & & 2898 & 1294 & 2087 & 2357 & 1912 & 1640 & 1084 & 2869 & $26 »$ \\
\hline ENGINE & 612 & 1351 & - & 941 & - & 1600 & 321 & 1511 & & 1424 \\
\hline ENVIR & 121 & - & - & & 1137 & 900 & & & & 974 \\
\hline LAW & - & 649 & 556 & 192 & 809 & 740 & 609 & & 325 & 1400 \\
\hline MED & - & 1826 & 1228 & 2253 & 771 & 1225 & 352 & 669 &. & 1205 \\
\hline PRARM & & 592 & & & 412 & - & - & - & & 1103 \\
\hline SCIENCE & 945 & 2987 & 2368 & 2584 & 1311 & 2463 & 801 & 2026 & 2398 & 1374 \\
\hline SOC.SC & & 3201 & 1257 & 1860 & 4487 & 2171 & 2567 & 1149 & 1249 & \\
\hline VET & & & & 449 & & & 145 & & & 454 \\
\hline OTHERS & & & & 28 & 1173 & & 800 &. &. & 4452 \\
\hline $\begin{array}{l}\text { Opumum } \\
\text { Size }\end{array}$ & 560 & 3000 & 1150 & 2000 & 1800 & 2120 & 1500 & 1920 & 1200 & 2100 \\
\hline TOT.AL & 2.096 & 15.435 & 8.634 & 13.858 & 14.561 & 14.068 & 9.200 & 10.825 & 9.954 & 20.954 \\
\hline
\end{tabular}

NOTE: Any discipline with enrolment lower than its optimum size is considered to be operating below an economically effective level

SOURCE

NUC Statistical Digest on Nigerian Universities 1988 -1992 pp 4 
out with more practical solution strategies, there will be need to study the expenditure pattern by university and over a long period of time.

Moreover, owing to the sensitive nature of some of the suggested measures, there is need to phase out the implementation such that there will be enough time to prepare the ground. Measures aimed at adjusting established pattern are usually resisted. Practitioners should therefore, do enough homework before announcing any of the measures suggested in this paper.

\section{References}

Akangbuo S.D. (1986): Financing Higher Education in Nigeria, Ibadan: University of Ibadan Faculty lecture.

Babalola J.B. et al (1996) Costs and Financing of university Education in Africa: The Nigerian Experience, AAU study programme on Higher Education Management in Africa.

International Development Association (1990) Report and Recommendation of the President of the International Development Association (IDA) to the Executive Directors on A Proposed Federal Universities Development Sector Adjustment Operation to the Federal Republic of Nigeria, IDA.

Kumar, R. (1981) Economies of Higher Education in Nigeria: A Case study of University of Ibadan Medicine Dissertation, Department of Educational Management. University of Ibadan.

World Bank (1988) Nigeria: Costs and Financing of Universities, Washington D.C.: The World Bank. 